\title{
Japan Banking Inc.: Problems, Solutions, And Implementation: An Economic And Cultural Perspective
}

Dennis Pollard, (Email: DPollard@fullerton.edu), California State University, Fullerton Shirley Chuo, (Email: SChuo@ Adelpia.net), American Intercontinental University

\begin{abstract}
The focus of this paper is to obtain a realistic estimate of real Japanese Bank Losses. The insights gained will include: Factors contributing to bad loans, method of disposal of bad loans, future prescriptions regarding the Early Warning System/Diversion Process will be put forth and conclusions for future economic methods to monitor guide turnaround.
\end{abstract}

\section{INTRODUCTION}

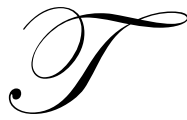

he 1976-1985 period in Japan could be described as one of impressive macroeconomic performance with economic growth in the range of $3-5 \%$, price stability, minor business fluctuations, internationalization, and emergence as the world's second largest economy and largest creditor nation. This period was an amazing period indeed for Japan's banks as well.

In an article published by The Banker in 1988, seven Japanese banks were ranked in the top ten banks in the world according to size of assets. (The Banker, 1988) However, just after ten years in 1998, The Banker only ranked three banks amongst the top ten in the world. (The Banker, 1998) During the 1990s and into the new century, Japan has gradually witnessed the collapse of its banking system.

What happened? This is the question that has been widely asked by many. In the past decade, there have been multiple theories attempting to answer this question. Surely, there is no one key factor that sparked this decade long economic slump and thus this paper will examine the collapse of the Japanese banking system factor and pose some potential strategies on how Japan can deal with this crisis.

First, the paper will discuss factors that contributed to the bad-loan problem. The second section will argue that the disposal of bad-loans should be dealt with by the government and not by the banks. Then, the paper will discuss some strategies for dealing and preventing future pile-ups of the non-performing loans (NPs). Finally, the paper will provide some concluding comments.

\section{THE BAD LOAN PROBLEM: A CURRENT ENCOUNTER}

In determining the current size of the bad-loans, it is almost impossible to derive an accurate figure. Estimates range from the government's \$266 billion to Goldman Sachs' \$1.9 trillion. (Asiaweek, Nov. 2001) Without a proper estimate of the size of the problem, the government will confront difficulties in establishing sufficient cleanup policies.

According to independent bank analyst, Yushiro Ikuyo, one of the reasons of why it has been such a difficult process to derive an accurate estimate is that, "The Financial Services Agency (FAS) essentially accepts the banks' self-appraised bad-loan reports as they are, allowing banks to massage figures and keeping suspect loans in healthy categories." (International Business \& Finance Daily, March 2001) Another obstacle in deriving an accurate number is due to the current condition of the economy, which is sparking new cases of bad-loans at the same time banks 
dispose of old ones. According to Standard \& Poor's, \$28 billion of major banks' loans previously classified as "needing attention" went sour between October 2000 and March 2001. (International Business \& Finance Daily, March 2001) This leads us to another point, the classification of the bad-loans.

In the inspection manuals produced by the FSA, loans held by financial institutions are classified under four categories according to the conditions of the borrower including the ability of the borrower to pay back the funds and the adequacy of the collateral it has provided. The table below summarizes these categories. Loans in categories II through IV are considered problem assets.

Table 1. Classifications Of Loans

\begin{tabular}{ll}
\hline Classification Category & Characteristic \\
One (I) & Normal \\
Two (II) & Requiring Attention \\
Three (III) & In danger of bankruptcy \\
Four (IV) & Bankrupt or effectively bankrupt \\
\hline Source: Financial Services Agency &
\end{tabular}

Financial institutions have created their own loan portfolios on the basis of these criteria, and according to the self-assessment data distributed to the FSA, the problem assets at all Japanese banks as of the end of March 2001 is 30.6 trillion yen. The table below summarizes the figures more closely. Looking at this table, we can see that the balance of non-performing loans decreased in major banks, while it increased in regional banks, which resulted in an increase in the overall amount of estimated bad-loans.

Table 3. Balance of Non-Performing Loans

\begin{tabular}{|c|c|c|c|c|c|}
\hline & & \multicolumn{4}{|c|}{ In trillion yen } \\
\hline & & \begin{tabular}{|c|} 
End of March \\
1998 \\
\end{tabular} & $\begin{array}{c}\text { End of March } \\
1999\end{array}$ & $\begin{array}{c}\text { End of March } \\
2000 \\
\end{array}$ & $\begin{array}{c}\text { End of March } \\
2001\end{array}$ \\
\hline \multicolumn{2}{|c|}{ Non Performing Loans (all Japanese Banks) } & 26.7 & 29.6 & 28.6 & $30.6(+2.0)$ \\
\hline \multirow{2}{*}{ 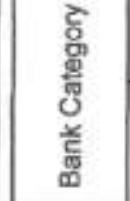 } & Major Banks & 18.9 & 20.3 & 18 & $17.4(-0.6)$ \\
\hline & Regional Banks & 7.8 & 9.4 & 10.6 & \multirow{2}{*}{$\begin{array}{l}13.2(-0.6) \\
10.6(+2.5)\end{array}$} \\
\hline \multirow{2}{*}{ 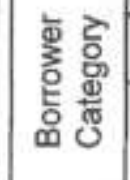 } & "Requiring attention" & 11.1 & 9.7 & 8.1 & \\
\hline & $\begin{array}{c}\text { "In danger of bankruptcy or } \\
\text { below" }\end{array}$ & 15.5 & 19.9 & 20.5 & $20.0(-0.5)$ \\
\hline
\end{tabular}

Source: Financial Services Agency 
With respect to the borrower categories, the loans to borrowers classified in or below the 'In danger of bankruptcy' category decreased due to final disposal. (FSA) Loans in the category 'Requiring attention' increased partly due to the heightened standard requirements for the bank self-assessments of assets; reflecting more rigorous inspections by the FSA. The FSA states that this is the primary reason for the increase of non-performing loans in regional banks. ${ }^{1}$

\section{THE BAD-LOAN PROBLEM: WHAT BROUGBT THE BANKS DOWN?}

Before examining the factors that led to the collapse of the banking system, it is important to understand that this problem "did not emerge in full-fledged form right after the bubble burst; instead, it slowly ate away at tile financial system as a whole over an extended period of time." (Kuroda) I $n$ other words, the problem was initially sparked with the bursting of the bubble, and it gradually became apparent as tile deflationary cycle progressed.

In focusing on what brought about the problems, this paper considers one of the answers discussed by Cargill (2000) and elaborated on by Hoshi (2000).

\section{Financial Liberlisation}

During the rapid economic growth period (19508 to 19708), the Japanese financial system was under heavy regulations. A domestic capital market that resembles that of other developed nations was repressed. Corporations were unable to utilize the different vehicles for raising capital such as bond issuance or new stock issues, but neither lenders nor borrowers had an option to rely on foreign markets in a significant way. This caused the Japanese corporations to depend on the banking sector for nearly all external financing needs.

Additionally, banks were regulated with respect to the 'Chinese Wall' mechanism of separating the operations of a commercial bank from that of an investment bank. ${ }^{2}$ Simply, brokerage houses were prohibited from taking deposits. There were also tough regulations in the insurance industry with fine lines separating different categories of insurance providers. Banks were limited to the traditional business of taking deposits and making loans. (Hoshi, 2000) The stringent regulations imposed on the banking business allowed for banks to deal with large clients, while shinkin banks and credit unions focused on their member firms, all of which were small. (Hoshi, 2000)

The financial liberalization began taking place in the late 19708. This process began with creation of a s ondary market for government bonds and gradually involved the debt and equity capital markets. Hoshi points out that the relaxation of foreign exchange control in 1980 and in 1984 opened a path for Japanese companies to obtain funding needs from abroad. ${ }^{3}$ (Hoshi, 2000) Eventually, Japanese companies began to explore other methods of meeting their financing needs aside from standard bank borrowing. For example, Hoshi examined the ratio of bank loans to total assets for large manufacturing firms in Japan. He concluded that this ratio was at 35\% in the 1970s and had declined to $15 \%$ by $1990 .{ }^{4}$ Large non-financial firms that were good customers of major banks started to turn away from banks and use the securities market. (Ueda) This deviation by large companies from standard bank borrowing perhaps suggests that corporations began to understand the benefits of alternative methods for financing their operations.

As the large customers moved away from bank financing, the banks were forced to look elsewhere to generate business. At this point, they began to focus their attention on small and medium size firms. Figure 1 shows such a style shift in customer base for Japanese banks. ${ }^{5}$ The large companies could be characterized as already established firms that belong to one of the major keiretsu groups. ${ }^{6}$ Hoshi (2000) also examines an interesting aspect of this shi the decline in proportion of keiretsu loans. Since most of the listed firms in Japan belong to a particular keiretsu group, the proportion of bank loans to listed firms also displays a declining trend. This is portrayed in Figure 2 established by Hoshi (2000).

A major problem with this shift in customer base is that these banks had little knowledge about their potential clients. But, in order to counter the decline in the banking business, the banks needed a new client base. To balance the risk for the lack of information on these smaller transactions, the banks required collateral for the loans. At that 
time, land was the most secure answer. As it is well known, Japan lacks land space and land was highly sought after. Interestingly enough, with the exception of a brief period in 1975, the 1990s have been the only postwar period in which land prices have exhibited major downward tendencies. (Ueda)

Figure 1. Proportion of Bank Loans to Small and Medium Firms *

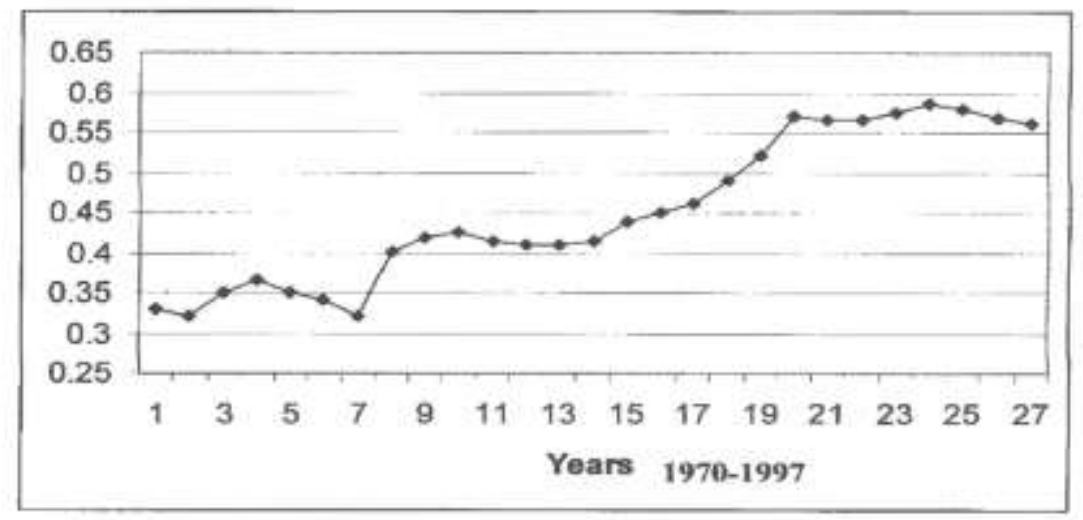

Source: Hoshi (March 2000)

Bank of Japan Statistics Quarterly, various years.

-Note:

The small and medium companies according to the Bank of Japan are those than are not considered 'large'. BoJ considers large companies to be ones that have more than 100 million yen in equity and more than 300 regular employees.

At that time, the real estate and construction industry looked promising for those banks that started to engage in collateralized style lending. The credit analysis in these transactions according to Ueda (2000), was a matter of estimating the future path of real estate prices. As discussed above, the trend in the appreciation of land value was positive, so for many of the banks, the risk perceived was minimal. Large banks also began to loosen their lending policies and began to search for business amongst smaller firms, thus enhancing competition for smaller banks, who in return began their own laxation of lending policies. Figure 3 was produced by Hoshi (2000) and displays the steep incline in the proportion of loans to the real estate industries in the 1980s.

When the land prices in the 19908 began to decline, many of these loans became non-performing and the collateral lost their values. This has in deed contributed to the bad-loan problem.

\section{The Response Was Too Slow: "Wait-And-See" Policy}

Many have argued that the government was to slow to act to this problem even after it was evident that the problem existed. When Japan began to witness sporadic failures in its banking sector, many thought these to be isolated events and posed little or no systematic risk. Despite the decline in the stock market in the early 1990s after the bubble, the atmosphere in the financial community was that of optimism. Many felt that Japan would smoothly transition out of this wave of economic decline. In fact, the economy had continued to show a positive growth rate. albeit at a slower pace. (Nakaso, 200 1) This led to the expectation that asset prices and thus collateral values would once again appreciate. This expectation prompted the authorities to adopt a less active stance against studying and combating the situation, and thus they adapted to the wait-and-see approach. 
Figure 2. Keiretsu Loans and Loans to Listed Firms

- Keiretau Loans a Loana to Listed Firms

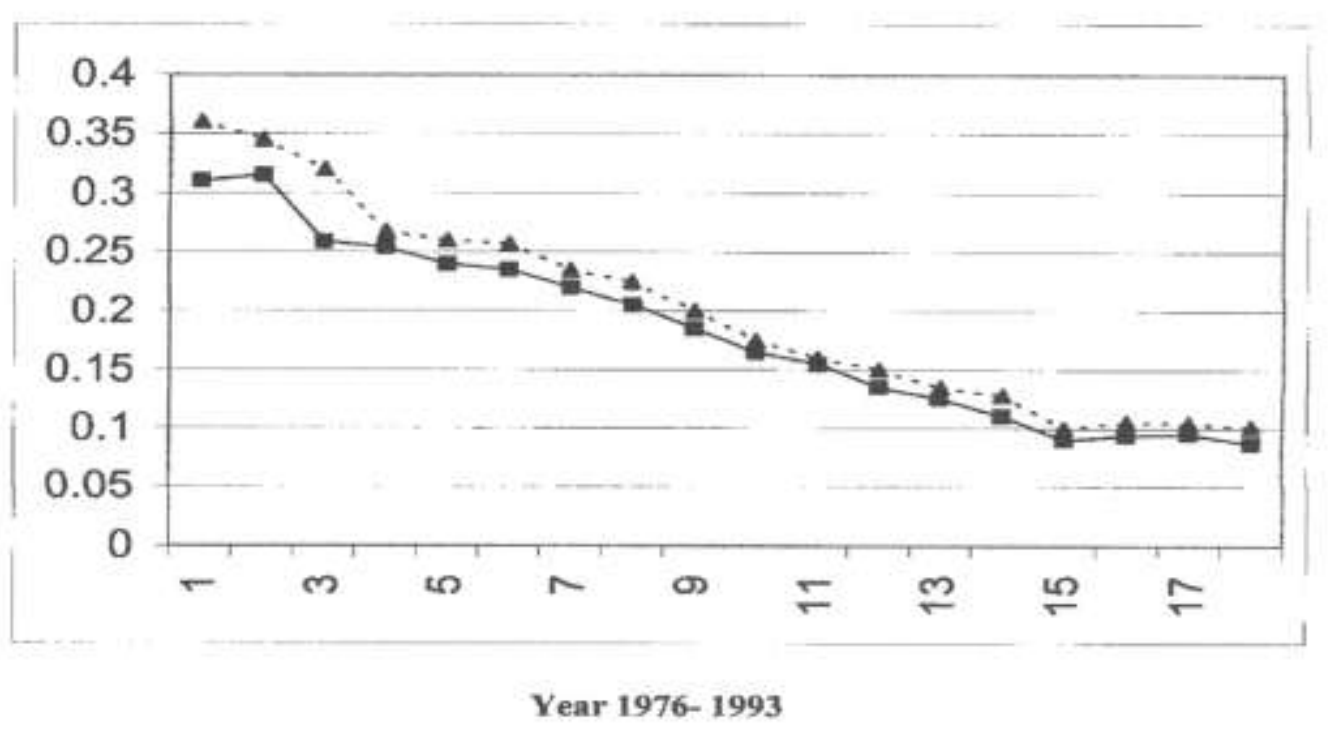

Source: Hoshi (2000 March), Kezai Chosakai, Kin 'yu no Toyushi.

\section{Lack Of Disclosure And Transparency}

Throughout the 1990s, the Ministry of Finance (MOP) has delayed the recognition of the bad-loans (a.k.a. non-performing loans (NPLs) and had demonstrated reluctance to take action against troubled institutions. For example, the MOP allowed the jusen (financial institution subsidiaries concentrating in real estate loans), to hold NPLs without special write-offs even though the Ministry had examinations in 1991-1992 that revealed 67 percent of the jusen's loans were already non-performing. (Gordan. 1999) According to Ikuyo, this is another reason why the bad loan sum rose, not fell, reflected the problem of examination. (International Business \& Finance Daily, March 2001) Simply, the authorities allowed these institutions to adopt accounting practices that manipulated the figures by delaying and in some instances concealing the effect of land and stock price declines on the value of reported assets.

In Gordan (1999), Beason and James $(1999,1984)$ note that the opaqueness of Japanese financial reporting, compounded by the MoF's unwillingness to disclose the magnitude of the crisis, helped fuel unrealistic and irresponsible estimates of the magnitude of Japan's bad debt problem. Now that the problem is overwhelming, the government has realized the true effects of an inferior financial reporting system. With regard to the ineffectiveness of the Japanese financial reporting system, Gordon (1999) quoted the Bank of Japan's Deputy governor (Fujiwara) as saying:

...the dominant view used to be that 'disclosing the amount of non-performing loans required careful consideration because it might induce disturbance in the financial system'. In addition, the accounting systems and practices tended to obscure the real business condition of financial institutions. Such circumstances increased the lack of transparency with respect to the management of financial institutions, and, accordingly, accelerated the deterioration in the credibility of Japan's financial system as a whole. 
Figure 3. Proportion of Loans to Real Estate Industry

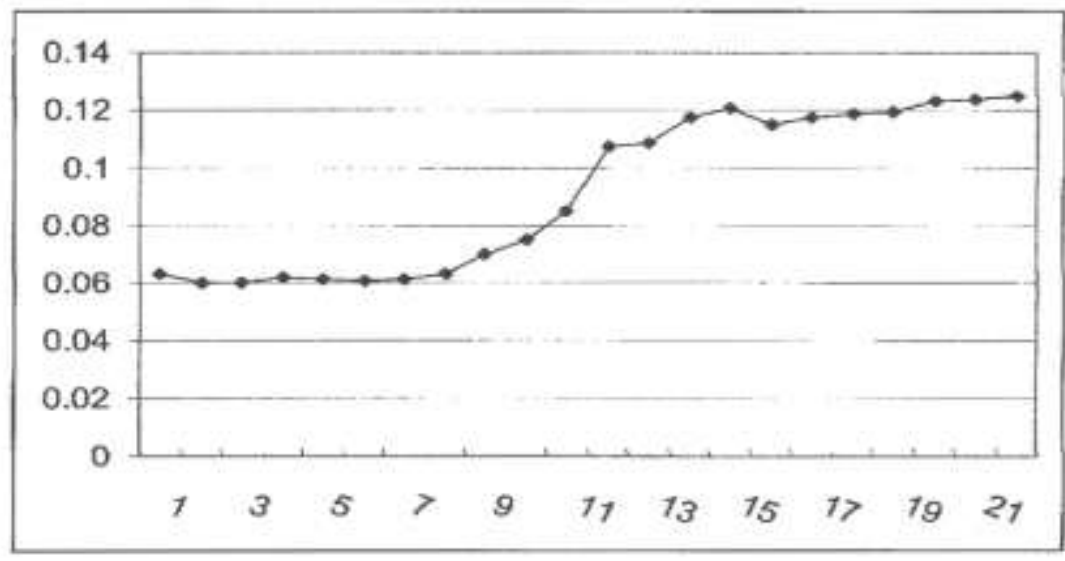

Years 1976-1997

Source: Hoshi (2000 March)

Now that we have reviewed some of the leading causes that contributed to the current bad-loan problem in Japan, we can explore some measures that the Japanese can take to help eliminate this ever-growing problem. And thus, the third section will look into some of these measures.

The next section will also contest the assumption that the banks should be left to deal with the NPLs problem. Many experts on this matter have agreed with this notion and displayed concern about the potential increase in problems for the banking sector, if otherwise. For example, at a 17 July 2001, ESRI Economic Policy Forum, keynote speaker and Tokyo University professor, Horiuchi, when addressing the matter, expressed his views, that the most appropriate judge of NFL is the bank itself and thus the disposal of NPs should be left up to the banks' own decisions. (Minutes from ESRI Economic Policy Forum) The point the paper will attempt to make is that because banks in the past have not faced stringent measures, they were able to engage in actions that eventually created the current problem. Given the fact that banks in the past decade don't have an impressive track record in their efforts to dispose of bad-loans, the government must take matter into its own hands, and thus initiate the menacing task of badloan disposal.

\section{BAD-LOAN PROBLEM: GOVERNMENT INDUCED DISPOSAL}

The resolution of the non-performing loans problem must be the top priority on the policy agenda of Prime Minister Koizurni's cabinet states Senior RIETI Fellow Tsuru Kotara. (RIETI Columns, Kotara) It is inspiring to hear this from a Japanese perspective. The proper disposal of NPLs can be highly beneficial and bring prosperity once again to the island nation. In the Second Annual Summit on Real Estate Finance \& Securitization in Japan on the 26 May 1999, with regards to the NPLs problem, Ambassador Thomas S. Foley expressed the following: ${ }^{7}$

Perhaps the most important step for Japan's financial sector will be following through with the permanent disposal of bad assets. Reserving against losses is one thing but actually selling bad assets into the market - with government agencies hopefully taking the lead - can improve the long-term viability of the banks, help create the right conditions for stability and recovery in the real estate markets, and thereby lead to improved consumer and business confidence. 
Advocates of the idea that banks should be left alone to deal with their NPLs problem including Professor Horiuchi, who at the same ESRI Economic Policy Forum as mentioned above, implied that the initial stages that set the way for the creation of these bad-loans was sparked by the 'essentially private business' nature in the lender/ borrower relationship. As the need for bank financing deteriorated, the banks began to venture into risky lending transactions, which were allowed to happen by strong relationships between the participants. This relationship was established over many years and perhaps over many long nights at a local izakaya Japanese style bar, is difficult to break. According to Kotaro (RIETI Columns, 2001), regulatory authorities should not give banks free hand in the disposal of NPLs. For a bank to dispose of the NPLs could mean risking the destruction of this tightly knit relationship. This is one reason why banks might have a hard time taking the initial steps to dispose of the loans. On this issue, Kotaro interestingly concludes that, "...structural reform should be aimed at breaking past 'non-performing' relationships". (RIETI Columns, 2001)

Now that it is evident that the banking sector in Japan is under scrutiny domestically and internationally, Japanese head of banks are concerned about their reputation and thus fear the potential of a backlash from the disposal of NPLs. Kotaro (RIETI Columns, 200 l) mentions that "reputational concerns" has been recently looked at widely as a contributor to the pile up of the bad-loans. For example, bank managers may hesitate to write off NPLs immediately, since such actions might indicate their mismanagement of loans. Kotara (RIETI Columns, 2001) also states that, "Bank regulators, who want good reputations as capable monitors, may postpone the closure of insolvent banks and delay the drastic resolution of the NPL problems."

Another reason why banks might delay the disposal process has to do with lending practices in the 1990s. Even after the 'bubble' collapsed, loans to the real estate industry continued to increase despite the surge in real estate projects going sour. This lending behavior can be characterized as "soft budget constraints" (the refinancing of lossmaking enterprises), according to Kotara. (RIETI Columns, 2001) Soft budgeting will evolve for example, in a situation where banks have incurred sw1k costs in past lending relationships. ${ }^{8}$ In Japan, this implies the real estate sector. Thus there is an incentive for banks to extend further loans to these unprofitable projects and recover their loss if refinancing is expected to yield any sort of profit. Even if real e state loans were not performing, banks tended to build up "loan-loss provisions" for them, while waiting for land prices to recover, rather than carry out "loan-loss write-offs" and remove NPLs from their balance sheet. (RIETI Colwnns, 2001) The optimistic attitude amongst Japanese bankers that the current market downturn is a short-lived crisis and recovery in the real estate prices is near, needs a second glance. Given what is known about the trend in land value in Japan in the past decade leaves no room for optimism about a near-future appreciation in land prices. It's been over a decade and the end of this problem is nowhere prevalent. As senior bank analyst at HSBC Securities Japan, Brian Waterhouse correctly stated, "Even the Great Depression of the 1920s did not take this long to sort out." (FEC Review, Nov 2001)

Another explanation why banks could delay further the process of bad-loan disposal is the fear for potential negative short-run effects on the macroeconomic level. For example, bank balance sheet adjustments on a sector wide basis could have deflationary effects, thus enhancing the levels of bankruptcies and the level of unemployment. In a recent study conducted by the Director General for Economic Assessment and Policy Analysis, an estimated figure in the range of 390 and 600 thousand employees may lose their present jobs and that between 130 and 190 thousand may be left unemployed if these loans are written off within the next two years. (June 2001) With this in mind, banks will hesitate with the reforming process partially due to the expectation that the increase in unemployment and bankruptcies will inflict a greater blow to the already ailing Japanese financial sector.

In his campaign preceding the late April election in 200 I, Koizumi vowed to push through reforms "without being afraid of pain, being afraid by those who have vested interests and being hampered by previous experiences." (Bloomberg May 2001) The public by now is well aware about the potential downside effects of structural reform. This perhaps is a good time to acknowledge the widely used slogan of" No Pain No Gain." Professor Ikeo of Keio University expressed the following views from a macroeconomic perspective about the disposal of NPLs:

Structural change has a positive pressure on economic performance in the long run, but it generates negative impact in the short term such as unemployment. "Thus political leadership is necessary to advance structural change policies, which is inevitable for people to struggle with short-term negative shock. Japan's political actions in the 
1990s, which avoid unemployment risk in the short run, might have resulted in weakening the long-term employment capability of its economy.

At this stage of the problem, the Japanese are 1eft with very few choices and thus must absorb the pain, but at the same time be optimistic about the long-tern effects of reform. The longer it takes for the banks to resolve their problems, the more the severity of the problem becomes.

Looking at the potential benefits of reform, disposal of bad-loans by banks could lead to the international community to once again have credibility in the Japanese economy and companies. Regaining confidence from the international community is an essential element for the Japanese banks to once again become competitive and gain market share.

A final argument against the position that banks should be their own bosses in dealing with the NPLs is the fact that there has been very little progress in the disposal process. According to Paul Sheard, Chief Economist at Lehman Brothers Asia "Existing NPL problem in the financial sector in a country implies that the financial system of the CO1Ultry does not work". (ESRI Economic Policy Forum Minutes) Even though banks now have written off many of the non-performing loans on their books, according to remarks made by U.S. Ambassador Foley in Tokyo, they have not moved very aggressively to dispose of these claims, or the assets underlying them. ${ }^{9}$ According to recent statistics, the eight biggest banks, which include Mizuho Holdings Inc. and Sumitorno Mitsui Corp., said in November their combined bad loans had risen 14 percent since the start of the fiscal year in April to 20 trillion yen. (Bloomberg, Jan 2002) The continual growth of the NPLs indicates that there is inefficiency with the current measures attempting to combat the problem. To this regard, Ambassador Foley mentioned that, "the U.S. experience shows that it will be very, very important for the government to catalyze tIle market by taking the lead in asset disposal, by selling or securitizing the foreclosed properties and bad loans under its control. During the Great Depression, the US swiftly implemented a sweeping disposal of NPLs in the middle of a severe deflationary current. As a result, the credibility of the financial system was restored. (Asia Times, Dec 2001)

The above section examines different arguments of why the government should be the proper authority in dealing with the NPLs problem. The government's lax policies in the past to dealing with the NPLs have been somewhat ineffective and, in fact, have paved a path for the introduction of new bad loans into the economy. For the benefit of the entire Japanese economy, it is essential for the government to take a pro-active stance in combating the NPLs problem. Given the current condition of the economy, a further delay in response could only lead to greater hardship.

\section{PROPOSED STRATEGIES: DEALING WITH THE BAD-LOAN PROBLEM}

At this point in the paper, it is safe to conclude that action must be taken to attempt to reduce or fully eliminate the bad-loans from the Japanese financial sector. In addition to attempting to abolish the NPLs from the financial structure, it's just as important to prevent this from occurring again in the future. The following section will introduce some strategies that might initiate this gruesome task.

\section{Dispose Of The Bad-Loans}

First it is necessary for financial institutions to eliminate the bad debts from their balance sheets, whether by selling them or by disposing of the collateral.

\section{Liquidation At Fair Value}

There will be no economic recovery in Japan until these problem assets are liquidated at their fair value. The only way to determine the value of these assets is to sell them for whatever they will bring; they have no value other than what people will pay for them. (Wallison, 2001 ) 


\section{Create An Auction}

Since Japan lacks a proper accounting system, it will be difficult to establish true values. Assessment of loan performance outside of Japan is difficult since the information of the borrower is almost monopolized by the lenders (banks). (Horiuichi, ESRI Economic Policy Forum) Therefore, they must be sold at an auction. According to Wallison (200!), the only way to encourage bidding is by the largest possible crowd. The greater the number of bidders, the greater the potential for good prices.

Wallison also points out that foreign bidders must be welcomed to participate in the bidding. This could very well lead to the best prices offered. Despite the current global economic slump, there are many companies offshore that are still cash intensive and might consider the current economic condition as an opportunity to expand. This is also a way for foreign companies to penetrate the Japanese market The increased competition at home could be a stimulant for Japanese corporations to rethink their current strategy, and thus prompt them to adopt a more innovative operational goal.

\section{Recapitalize The Banks}

The sale of assets at fair value will cause banks to incur huge losses, thus making some banks insolvent. The decrease in capital will also shrink the role of banks and bring down the level of lending activity. In Diamond (2000), it's argued that too little capital may be worse than none, and too much will be wasted. When recapitalizing the banks, the government should adopt measures to properly assess the needed amount of funds by the banks.

\section{Stringent Risk Management}

As mentioned above, a contributing factor to the build-up was the banks' reluctance to properly evaluate their loan clients. To prevent this sort of situation from happening again, Japanese financial institutions must adopt more stringent policies in assessing credit risk. According to a study by the Director General for Economic Assessment and Policy Analysis, a conclusion was made that because loans continue to go bad today seems to indicate that the financial institutions practice insufficient risk management and their market discipline is weak.

In a fast paced business world, opportunities for new business ventures are wide open, meaning initiatives that proved profitable before might not bet he case now. F or this reason, Japanese financial institutions should change their traditional business lending strategies and adopt one that bases the lending decision on the potential profitability of separate business segments or ventures. As the financial markets of the world become more integrated, the outcome of financial transactions is now riskier. Accompanying this risk is the potential for high profits given that companies thoroughly assess the risks involved within each transaction.

\section{Open Policy In Corporations}

Japanese corporations need not to harbor a corporate environment where it's difficult for individual workers to point out problems if they exist. Corporations should encourage employees to speak out when a problem or potential problem is detected. Gordon (1999) discusses a study by Keizai Koho Senta, which gathered information from company employees throughout Japan on why scandals in companies occur. One of the top answers was a company environment that made it difficult to point out problems. The same survey by the Kezai Koho Senta, mentioned in Gordon (1999) concludes that increased disclosure requirements and audit reviews to prevent financial scandals may have limited effectiveness due to a company environment established by management that does not encourage problem disclosure and that does not clearly prohibit unethical and questionable actions. In many cases, problems in companies become apparent at the lower level of the management hierarchy. Even with the acknowledgement of the problem, many times it goes unreported. Encouraging communication and firm wide evaluations could prevent problems from reaching severe levels. 


\section{Adopt A More Stringent Accounting System}

Wide-spread bankruptcies and scandals in the 1990s have led the international community to discredit the accounting practices in Japan. For example, the financial institutions understated the extent of their non-performing loans by a combination of illegal fraud and accounting trickery designed to produce misleading financial numbers but allowed under the loose disclosure requirements in place at the time. (Ozaka 1998 28-9; Schaede) in (Gordon, 1999) Two historical examples would be in the case when Cosmo Credit Cooperative and Kizu Credit Cooperative prior to their failure reported bad-loans figures to be estimated at 2.4 billion yen and 32 billion yen respectively. It was later discovered that these figures were vastly understated and the true figures were at 350 billion yen and 800 billion yen for Kizu, respectively. (Gordon 1999) ${ }^{10}$

The adoption of an external accounting board or accounting standards that resembles that of the Generally Accepted Accounting Principles (GAAP) in the U.S. could prevent or limit potential scandals. The establishment of effective accounting measures will benefit the entire Japanese economy and help the financial sector to get back on its feet. It would also eliminate foreign imposed policies such as the "Japan premium", Tougher accounting measures will also attract investment and provide company public relations. If a company does not disclose its information to the public, then the public could only be led to question the financial health of the company, Japanese companies should be encouraged to no longer view accounting disclosure as maximum standards and voluntarily disclose information as a mechanism to becoming a globally competitive organization.

\section{CONCLUSION}

The 1990 's has been a tough period for the Japanese economy. The stock market has devalued by over 70 percent from its all time high in the mid 1 980s. Despite many debated reasons for the cause of the downward trend, the creation of non-performing loans after the collapse of the bubble can be a leading candidate for explaining the ailing economy. It's safe to assume hat the NPLs has helped trigger this decade long debacle in Japan's once flourishing financial sector.

The attitude towards riding the financial sector of the bad-loans has been one of delay. It has been over a decade and still bad-loans are being reborn into the economy. The shear existence of these loans today long after the problem was uncovered implies the ineffectiveness and inadequacy of the measures taken.

Many officials have before vowed to combat this problem haunting the financial sector, but few took action. Recently, there has been optimism from all angles about the current administration of Mr. Koizurni's claims that it will enforce reform regardless of how much pain is inflicted into the economy- The mere fact that this administration has acknowledged and made public the potential short-run negative effects is inspiring. Now its time for action and the government must take the initiative.

This paper argues against the stance that bad-loan disposal should be left up to the banks. Individuals in favor of this argument believe that only the banking institutions can dismantle this problem, because of the close relationship between lender/borrower that managed to get banks into this situation in the first place. This view is valid and widely understood and as mentioned above, that's a leading reason why not to allow banks to be responsible for the disposals. The banks could in fact still have residing relationships with these clients that might be difficult to break and thus delay the balance sheet adjustment process.

The paper provided other reasoning of why it's crucial for the government to lead the disposal efforts. Ever since the problem became apparent, financial institutions by no means have displayed a proven track record that leads us to assume that they will proceed with the necessary stages. For many banks, a disposal of loans is a sign of weakness in terms of management practices. Thus, very few bankers will be willing to damage their reputation further and face up to their losses. As Takashi Tachibana, a popular non-fiction author and critic, puts it in an issue of the weekly magazine Shukan Bunshun, Japan's bad loan problem no longer is an economic problem and it needs to be dealt with as asocial and societal problem. Leaders in $\mathrm{t}$ he financial community need to be less concerned about their reputations and be more concerned about the additional consequences of delaying the restructuring process. 
The paper also discussed some strategies to dealing with this problem. The government should open up the market and welcome bids for bad assets from overseas. Enhancing competition domestically could be a 'wake-up-call' for Japanese companies to alter business strategies and seek new innovations. One way for Japanese financial institutions to become more competitive is to adopt more stringent accounting measures. Due to the high volume of bankruptcies and scandals in the 19908, Japanese flInls have lost credibility on an international scale. This is evident by measures imposed on Japanese companies such as the "Japan premium" or the large number of investors fleeing the Japanese equity markets. Disclosure of financial information could regain some of that much needed trust back for Japanese corporations.

At this stage of the battle, there is not more room for talk. It's time to 'walk the walk'! Further delay in action will cast a 1arger shadow over the struggling financial system. Until the government begins the grueling responsibility of bad-loan disposal, the sun will not shine on the financial sector in the land of the rising sun.

\section{FOOTNOTES}

1. For more details on the different statistics regarding the bad-loan problems, see the FSA report on Issues in the Financial Capital Market and Measures Addressing Them.

2. $\quad$ For more details on the 'Chinese Wall', see the Glass Steagall Act of 1933.

3. 1980 was the reform of Foreign Exchange and Control Act. In 1984, the 'real demand principle' was abolished.

4. These figures were derived by Hoshi using data obtained from the Japan Development Bank.

5. These figures are taken from Hoshi (2000). What happened to Japanese banks?

6. For more details on the keiretsu system, see Miyashita and RusseU (1994), Keiretsu - Inside the hidden Japanese conglomerates.

7. For further details on the remarks made by Ambassador Foley, please see the US Embassy in Tokyo homepage on the Internet.

8. Sunk costs are costs already incurred in a project that cannot be changed by present or future actions.

9. Remarks made by US Ambassador Thomas S. Foley on May 26, 1999 in Tokyo.

10. For further details on bankruptcy and scandal cases, see Gordon. November 1999.

\section{BIBLIOGRAPHY}

1. Aritake, T., Bad Loans by Japan's Banks at $\$ 87$ Billion; Falling Land Prices, Bankruptcies Blamed. International Business \& Finance Daily. (27 March 2001)

2. Diamond, D. W., Should Japanese Banks be Recapitalized? Institute for Monetary and Economic Studies. Discussion Paper Series No. 2000; v. E-29 (Sept 2000)

3. _ Director General for Economic Assessment and Policy Analysis. Study Project on the Potential Influence of Balance Sheet Adjustment. (28 June 2001)

4. $\quad$ ESRI Economic Policy Forum. Non-performing loan problems in Japan and their solutions. (11 July 2001)

5. _ Financial Services Agency. Issues in the Financial Capital Market and Measures Addressing Them. (28 August 2001)

6. $\quad$ Gordon, W. D. A Critical Evaluation of Japanese Accounting Changes Since 1997 (Nov 1999)

7. Horiguchi, Y., Crisis Prevention: Time for Japan to Act. Asian Wall Street Journal. (20 Sept 2001 )

8. Hoshi, Takeo., What Happened to Japanese Banks? Institute for Monetary and Economic Studies. Discussion Paper Series No. 200 I. Vo. E- 7.

9. Iwasaki, M., Sekioka, T., Hirose, T., and, Imaizumi, R., Japan Sets Stage for public Fund to Banks. (Update 2) (7 January 2002) www.bloomberg.com

10. Kobayashi, K., Japan's bad loans a burden on capitalism. (7 Dec 2001) Asia Times Online http://www.atimes.com/japan-econ/CLO7DhOI.htmI

11. Kotara, T., Stop rolling over the bad loan problems. Research Institute of Economy, Trade and Industry (RIETI) Columns (2001) 
12. Kuroda, A., The Problem of Bad Loans in the Japanese Financial Sector. www .japan-emb.org.sg/ JapanAccess/badloans.html

13. Murakami, M. and Lee, C., One The Brink: Japan's sinking economy is pulling banks further into another quagmire. But Tokyo is reluctant to take drastic countermeasures. Asia Week. (23 Nov 2001).

14. Nakaso, H., The Financial crisis in Japan during the 1905: how the Bank of Japan responded and the lessons learned. Bank For International Settlements Papers. No 15. 6. (Oct 2001)

15. Schultz, J., Cracking Down; The body entrusted with reforming Japan's failing banking system is finally talking tough. Far Eastern Economic Review. (Nov 2001)

16. Seidman, L. W., How the U.S. Experience Can Be Useful to Japan. Bank Director Magazine. (Q4 2001)

17. Ueda, K., The Japanese banking crisis in the 19008. Revised version of (Ueda 1998).

18. Wallison, P., Five Principle for Dealing with Non-Performing Loans. American Enterprise Institute for Public Policy Research Papers and Study. Presented at Conference sponsored by the Research Institute of the Ministry of Economy, Trade and Industry in Tokyo. (25 Sept 2001).

\section{NOTES}

